\title{
Airborne geophysical survey of the catastrophic landslide at Stože, Log pod Mangrtom, as a test of an innovative approach for landslide mapping in steep alpine terrains
}

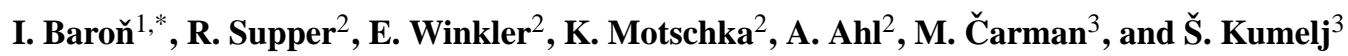 \\ ${ }^{1}$ Karst and Cave Research Group, Department of Geology and Paleontology, Museum of Natural History, \\ Museumsplatz 1/10, 1070 Vienna, Austria \\ ${ }^{2}$ Geological Survey of Austria, Neulinggasse 38, 1030 Vienna, Austria \\ ${ }^{3}$ Geological Survey of Slovenia, Dimičeva ulica 14, 1000 Ljubljana, Slovenia \\ * on leave: Geological Survey of Austria, Neulinggasse 38, 1030 Vienna, Austria
}

Correspondence to: I. Baroň (ivobaron@ centrum.cz)

Received: 20 December 2012 - Published in Nat. Hazards Earth Syst. Sci. Discuss.: Revised: 19 August 2013 - Accepted: 21 August 2013 - Published: 17 October 2013

\begin{abstract}
Airborne geophysics is a promising method for investigating landslides. Here we present a case study of multisensor airborne geophysical survey at the catastrophic landslide Stože near Log pod Mangrtom in Slovenia, which was conducted in the framework of the European FP7th Project "SafeLand". Based on the survey itself and achieved results, we discuss applicability, limits, and benefits and costs of the method for investigating landslides in steep alpine terrains. Despite of several operational constraints, the airborne electromagnetic survey of the area well presented the lithological pattern and water saturation. The high resistivity regions mostly indicated drained slope scree and landslide mass, drained and loosened material of the moraine deposit in the tension zone of the landslide with present cracks and cavities. The minima of the resistivity pattern were attributed to the outcrop of marls rich in clay, to water-saturated moraine deposit above impermeable marls in the tension zone, and to water-saturated porous alluvial gravel and landslide scree along the Koritnica River. The magnetic survey proved to be inapplicable for such a small and rough area. The Potassium and Thorium maps, on the other hand, both well identified the regions of tension inside the landslide zone, outcrops of marls and dolomite, clay-rich colluvium, weathered zones along a regional tectonic fault, and alluvial deposits and deposits of debris flows, and the minima of the ${ }^{137} \mathrm{Cs}$ clearly revealed the zones of material removal due to recent mass movements.
\end{abstract}

\section{Introduction}

Thanks to rapid technological progress, the airborne geophysics has recently evolved into a promising method of investigating landslides due to rapid achievement of different geophysical data on the subsurface properties of large surveyed areas, as documented by a helicopter-borne surveying of the Austrian landslides of Sibratsgfäll (Supper et al., 2008) and Gschliefgraben (Supper et al., 2010, 2013); the approach was also successfully applied for investigating landslides in Norway (Pfaffhuber et al., 2010) and in Japan (Nakazato et al., 2006). Tofani et al. (2013) highlighted that the performances of airborne geophysics are increasing at a fast rate and that this emerging technique is currently used to investigate a large variety of landslide parameters, including fetures (e.g., peculiar morphological and geological structures) not easily sensed by more established remote sensing techniques. For more references on application the airborne geophysics to landslides, please refer to Supper et al. (2013).

Here we present the airborne geophysical survey of the Stože landslide, which is a catastrophic landslide triggered in 2000 in Slovenia. The survey was performed on 21 May 2010 in order to test the limits of applicability of airborne geophysics in a steep alpine setting with unfavourable survey conditions. The study was conducted as cooperation between the Geological Survey of Austria and the Geological Survey of Slovenia in the framework of the European FP7th Project "SafeLand". 


\section{Landslide at Stože and its geological settings}

The test area is situated in an alpine valley to the west of the Mangart Mountain (2679 ma.s.l.) in the Julian Alps in NW Slovenia (Fig. 1a). It has a very rough topography with local relief of $700 \mathrm{~m}$ in a distance of $1.7 \mathrm{~km}$ (Fig. 2). This alpine valley lying in the direction SW-NE was strongly reshaped by glaciers during the Pleistocene. In contrast to other parts of the Julian Alps, the superficial river network prevails over the karst discharge. The Mangart Mountain and the study area are mainly composed of Upper Triassic rocks, which consist of three different lithostrathigraphic units: (i) Cordevol massive and thick bedded dolomite in the NE part of the study area; (ii) Julian-Tuvalian calcareous marlstone, claystone and limestone in the central and western part; and (iii) the main dolomite in the lower part, where layers $0.2-1 \mathrm{~m}$ thick occur; the dolomite is highly fractured near the faults. Often $\mathrm{Pb}$ and $\mathrm{Zn}$ mineralization (mostly Galenite, Sphalerite and Markasite) occurs in the Cordevol layers in the study area (Jurkovšek, 1987). Geological mapping of the site proved the existence of very unfavourable geological conditions which controlled the landslide (Petrica and Špacapan, 2001), because the landslide occurred in glacial moraine sediments and slope scree and colluvium, deposited on tectonically highly fractured dolomite lying on impermeable layers of Triassic marly limestone and marl (Fig. 2c). As dolomite is an excellent aquifer, the ground-water level in the rock rises substantially during heavy precipitation, saturating the overlying soils rich in clay. Also three major fault systems with general strike NW-SE, N-S and NE-SW (Fig. 1b) could have played role in the landslide's control.

The Stože landslide was triggered on 17 November 2000. In the first stage of the event, a huge rotational landslide occurred mostly within the moraine deposits. The landslide was $300 \mathrm{~m}$ wide, $1.5 \mathrm{~km}$ long and up to $10 \mathrm{~m}$, locally even $50 \mathrm{~m}$, thick. The crown of the landslide is at an altitude of $1525 \mathrm{~m}$ a.s.l. The landslide subsequently transformed into a debris flow (Fig. 1c), demolishing about 20 ha of forest, the Predel pass road, and destroying part of the village of Log pod Mangartom situated about $4 \mathrm{~km}$ downstream. Seven casualties occurred in that village due to the debris flow. The major factors of the landslide and debris flow were a combination of unfavourable geological and relief structure combined with intense rainfalls in October and November 2000 with total $1638.4 \mathrm{~mm}$ of precipitation during the 46 days prior to the landslide event (Mikoš et al., 2007). During the landslide event, approximately 1 million $\mathrm{m}^{3}$ of material was displaced in the main landslide (Fig. 2a) and in two adjacent minor landslides (Fig. 2b). However, a huge amount of moraine deposits is still loosened and ready-to-slide in the tension zone of the landslide, especially in the crown (Fig. 2c). It was estimated that more than 1.5 million $\mathrm{m}^{3}$ of unstable material could still be mobilized within the landslide area (Komac, 2001; Majes, 2001; Petkovšek, 2001).

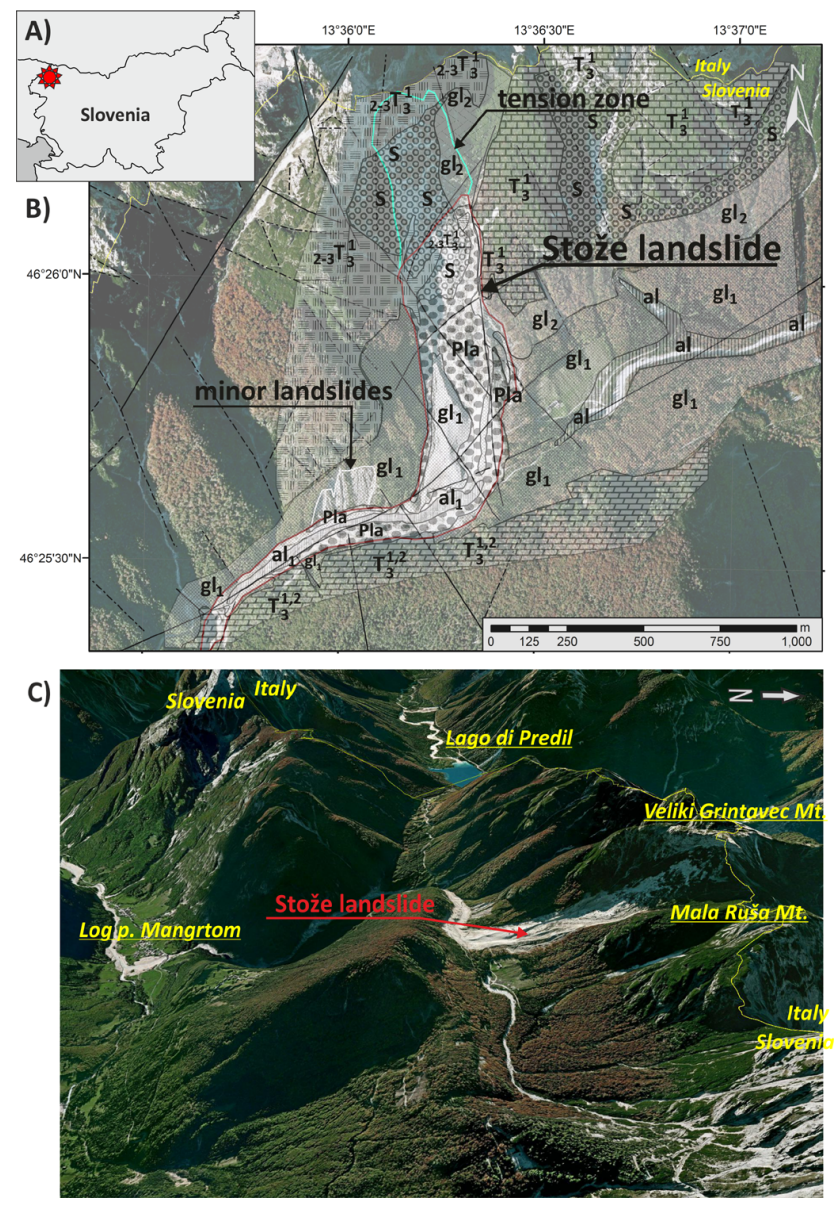

Fig. 1. Stože landslide: (A) location of the test site, (B) general settings of the site with geology modified after Petrica and Špacapan (2001) and Jurkovšek (1987) and mapped faults (full black lines) and with faults interpreted from topography (dot-and-dashed black lines) and (C) perspective view of the Google Earth orthophoto from E. Legend of the geological map: al1 - boulders, blocks and scree as remains of the landslide, loose; below $0.5 \mathrm{~m}$ clayey scree, clay, wood; $\mathrm{Pla}$ - the remains of the landslide: mixed clay, scree, sandy soil with blocks; potential mass for new LS; s slope scree, blocks of dolomite; al - aluvial gravel and scree, permeable; g12 - the remains of the morraine: clayey-silty soil with limestone scree and bigger blocks; low permeable; gl1 - mixed siltysandy to gravel-scree soil (= low cemented morraine), low permeability; $\mathrm{T}_{3}^{1,2}$ - main dolomite; layers $0.2-1 \mathrm{~m}$ with marl layers, near the fault the dolomite is highly fractured; $2+3 \mathrm{~T}_{3}^{1}-$ dark grey marly limestone, marly dolomite, marl, claystone; $\mathrm{T}_{3}^{1}-$ massive and thick bedded dolomite.

Some control of regional seismicity on the landslide triggering is also suspected as the entire region of NE Slovenia is a seismically very active area. On 12 April 1998, the strongest earthquake of the last $100 \mathrm{yr}$ occurred in the Upper Soča Valley, with the epicentre $10 \mathrm{~km}$ away from the Stože area. Its magnitude was 5.8 and its maximum intensity was between the VII and VIII degrees according to EMS. The 


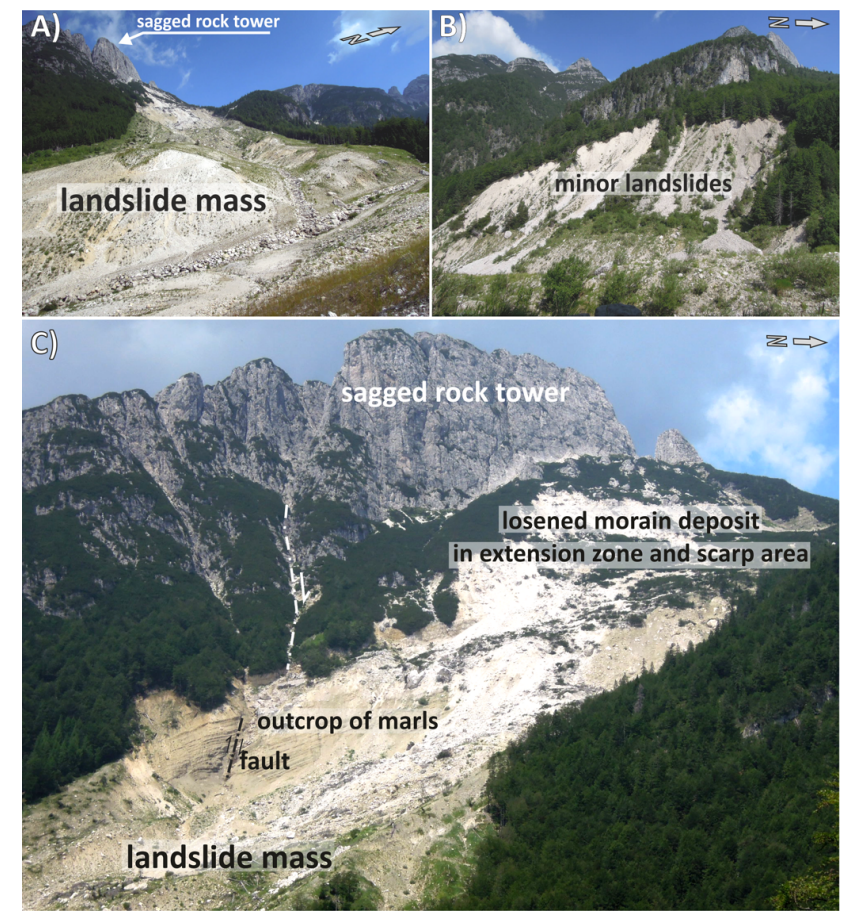

Fig. 2. Photos of the test site: (A) the accumulation zone with diamictic material of the landslide, (B) minor landslides above the place, where the major landslide transformed into the debris flow, and (C) upper part of the landslide with bare surface of the marly rock in the landslide's head scarp, and the tension zone comprising loosened moraine deposit; a sagged rock tower is marked as well (All photos I. Baroň).

hypocentre was located at a depth of $9 \mathrm{~km}$. Another strong earthquake shook this area on 12 July 2004. The earthquake with magnitude 4.9 caused the highest effects of VI to VII intensity according to EMS-98. The seismic focus was located at a depth of about $8 \mathrm{~km}$ (Vidrih and Ribičič, 1999, 2004). Although the landslide of the year 2000 was most likely triggered by heavy rainfalls in November, those strong seismic tremors probably had loosened the substrate of the subsequent landslide some time before the event and had been one of its most important predisposing factors.

\section{Methods and description of the field campaign}

For the test survey at the Stože landslide, we applied the helicopter-based geophysical system of the Geological Survey of Austria (Motschka, 2001). This system consisted of frequency domain electromagnetics, gamma ray spectrometry, and magnetics. Although the more detailed technical description of the applied airborne geophysical system with respect to landslide investigations was presented by Supper et al. (2013), here we summarize the most important information on the survey and its methods.

\subsection{Airborne frequency domain electromagnetics (AEM)}

The AEM method is intended to determine the distribution of the specific ground electrical resistivity using a system of co-axial and co-planar loops producing and receiving the primary and secondary (induced by the eddy currents in the subsurface) electromagnetic field, respectively. The method gives information mainly on porosity, water saturation, water conductivity of the pore fluid and clay content of the subsurface.

\subsection{Magnetic survey}

The magnetic survey measures the total intensity of the earth's magnetic field using Caesium-type magnetometer Scintrex CS-2, and deviations from the reference earth magnetic field (IGRF) are considered as anomalies. At low survey altitudes, the method could bring information on near-surface and local magnetic bodies such as ore deposits or artificial structures; however, for small areas and landslide studies in general it has a very low applicability.

\subsection{Gamma ray survey}

The gamma ray spectroscopy by one sodium-iodide crystal determines the natural and artificial radioactivity, which depends on the content of radioactive minerals within the first decimeters of the subsurface. Natural gamma radiation is essentially derived from three sources: the radioactive elements thorium (energy peak: $2.62 \mathrm{MeV}$ ), uranium (energy peak: $1.76 \mathrm{MeV}$ ) and potassium (energy peak: $1.46 \mathrm{MeV}$ ).

Potassium is one of the major elements of the earth's upper crust and occurs mostly in alkali feldspars and micas in felsic rocks as well as in clays as their weathering products (e.g., Illite). Thorium is present in the major rock forming minerals and it shows a high adsorption power to clay minerals, oxides and hydroxides. The primary sources of Uranium are granites and pegmatites; in sedimentary rocks, quartz rich sandstone and limestone contain low concentrations of Uranium, whereas due to the adsorption of Uranium in clay minerals, clayey sediments exhibit rather high values (Siehl, 1996).

The last mapped radioactive isotope is ${ }^{137} \mathrm{Cs}$. It is the only man-made nuclide, which is present in significant amounts in most soils on the Northern Hemisphere. In Europe, it deposited mostly due to atmospheric fallout from the nuclear power plant accidents of Chernobyl in 1986. It has the halflife of $30.17 \mathrm{yr}$ and it is still relatively abundant in European soils.

The survey was performed with a rental helicopter Ecureuil AS 350, which is a widely available type of aircraft, but with limited engine power for such surveys. Also, due to the limitation of the budget, not much time could be given to the pilot for training flights. Last but not least, weather condition during the survey period was quite bad with strong winds 


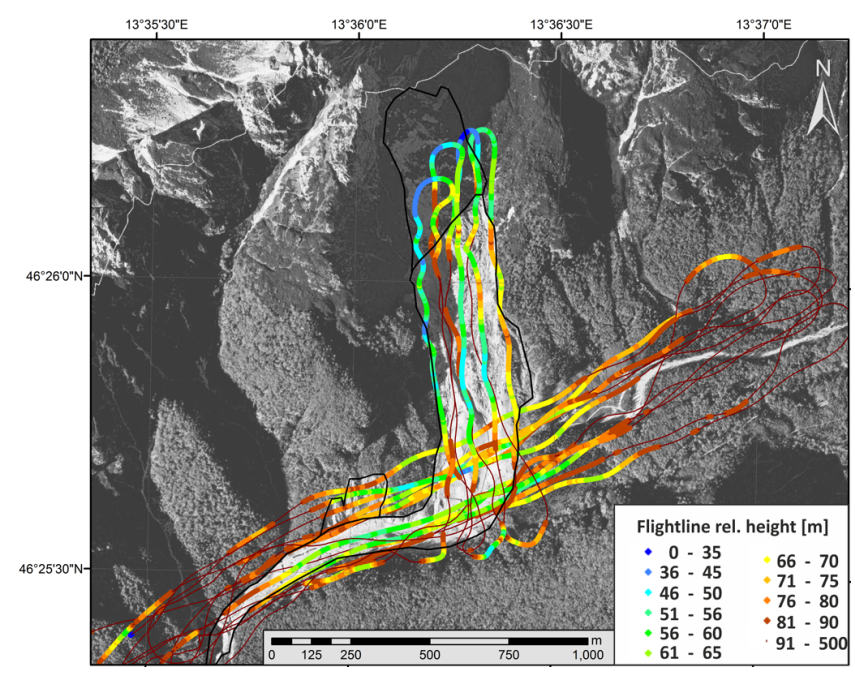

Fig. 3. Map of the flight lines over the test area at the Stože landslide, with indicated relative altitudes of the AEM sensor above the ground surface; note the altitudes over $90 \mathrm{~m}$, which are unsuitable for the survey (Source of data: Geological Survey of Austria and Google Earth).

at the top of the mountain ridge. Because of these strong winds the electromagnetic system could not be calibrated in between the lines at high altitudes, thus resulting in a much lower data quality than usual. Therefore, only a processing of the AEM data in the 1-D "homogeneous half-space" (Ahl, 2003) was reliable. The homogeneous half-space in AEM is the lower section of a three-dimensional Euclidean space, transected by a horizontal plane, with a homogeneous specific electrical resistivity. So it is limited in upward direction by a horizontal plane and laterally, as well as in downward direction, infinitely expanded. Since this model shows no variation of the specific resistivity within the half-space, it is called one-dimensional. In practice, the lateral dimension is basically limited by the footprint and the downward looking dimension is limited by the penetration depth of the geophysical method.

Due to the steep mountain ridges all around the study area, the survey flight was conducted only inside the valley and upand-down above the landslide body (Fig. 3) to cover as much area as possible. It is obvious that only a small quantity of the total area could be covered. Especially the electromagnetic results were sensitive to the sensor clearance. The reasonable results were achieved only from those flight lines, where the relative AEM sensor altitude ranged from some tens of meters to $90 \mathrm{~m}$ above the ground surface; this area is depicted in the maps with a light grey dot-and-dashed line. The data presented out of this area are just artifacts due to data interpolation and they do not represent the real situation.

The achieved resistivity, magnetic and radiometric results with output pixel resolution of $50 \mathrm{~m}$ were then interpolated (bilinear interpolation) and analyzed in the ArcGIS

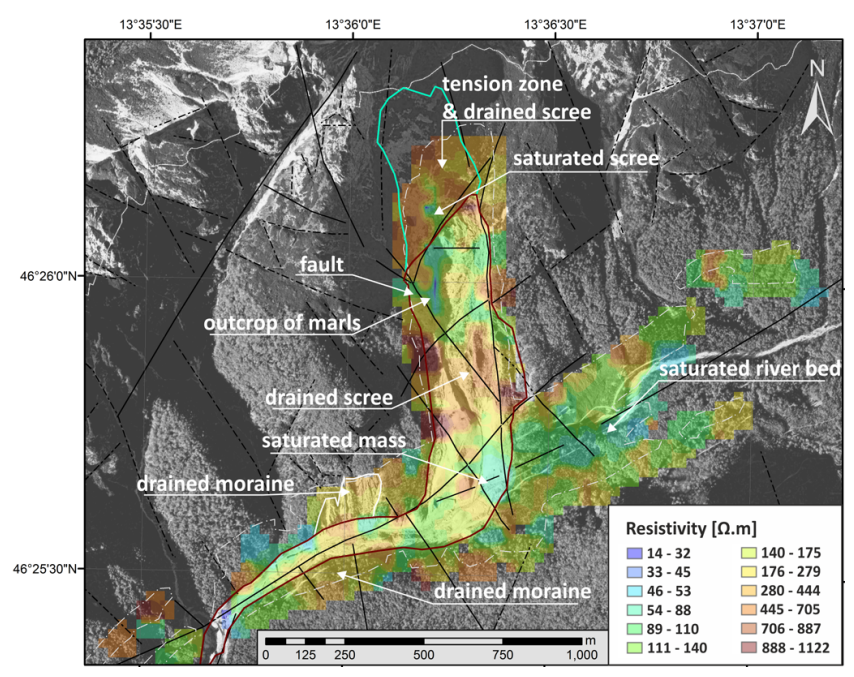

Fig. 4. Map of subsurface resistivity from the AEM survey, fault and joint pattern (black full and dot-and-dashed lines), area of reliable data (light grey dot-and-dashed line) and the geological interpretation (Source of data: Geological Survey of Austria and Google Earth).

environment and compared to the orthophoto obtained after the landslide event, and to the local geological maps (Jurkovšek, 1987; Petrica and Špacapan, 2001).

\section{Results}

In spite of the unfavourable survey conditions mentioned in the section above, the multi-parametric airborne geophysical survey brought some interesting results concerning the subsurface structure and about actual slope-related processes.

The resistivity pattern of the area achieved from the AEM survey showed local zones of minima, ranging from 14 to $45 \Omega \mathrm{m}$, in the NW part of the landslide and in the lower central (southern) part of the tension zone (Fig. 5). Other zone of minimum resistivity (from 33 to $53 \Omega \mathrm{m}$ ) occurred along the Koritnica River east of the landslide, in the southeast part of the landslide and in southwest part of the surveyed area adjacent to the debris flow (Fig. 4). On the other hand, relatively high resistivity values between 222 and $1122 \Omega \mathrm{m}$ prevailed over the rest of the surveyed area.

The map of magnetic anomalies is presented in Fig. 5. The results showed a distinct $\mathrm{N}-\mathrm{S}$ elongated minimum ranging from -268.9 to $-260 \mathrm{nT}$, located at the centre of the landslide parallel to the main sliding vector. The magnetic results are, however, strongly sensitive to a constant flight relative altitude above the ground surface, and thus in this case are difficult to be interpreted in detail.

The gamma ray survey, presented in this study, focused on the elemental concentrations of Potassium, Thorium, Uranium and Cesium. The pattern of Potassium content in the shallow subsurface is presented in Fig. 6. The relative 


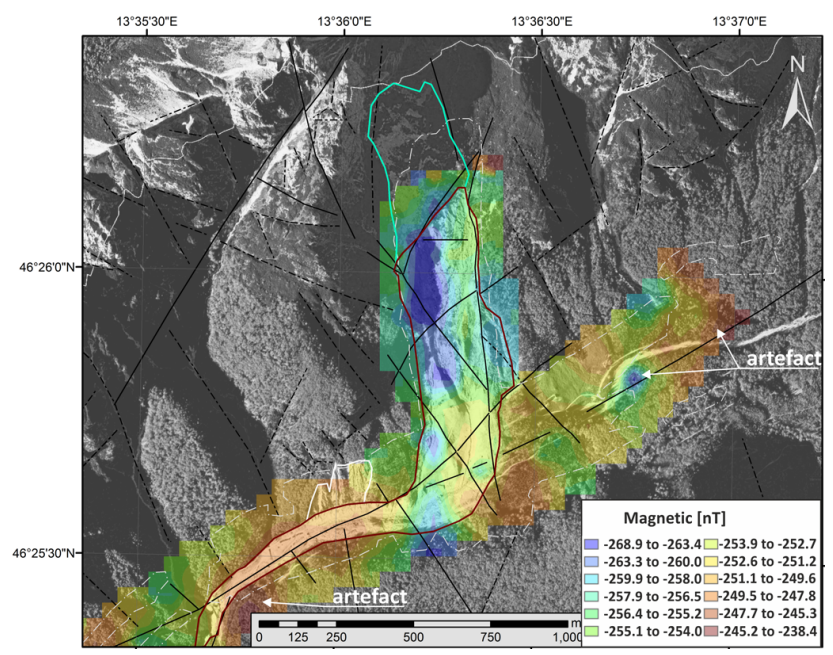

Fig. 5. Map of magnetic anomalies combined with the fault and joint pattern (black full and dot-and-dashed lines), and area of reliable data (light grey dot-and-dashed line) (Source of data: Geological Survey of Austria and Google Earth).

maxima of Potassium content ranging from 1.8 to $2.9 \%$ were registered mainly in (i) relatively flat area composed of moraine deposits with well-developed soil cover to the $\mathrm{E}$ of the landslide, (ii) in relatively wet area with colluvium, and swamps above moraine deposit to the NE of the tension zone of the landslide, and (iii) above an outcrop of marls within the landslide scarp (Fig. 6). The most distinct areas of minima $(0-0.53 \%)$ were registered (i) in the tension zone of the landslide, (ii) on the moraine deposit exposed by the major landslide and two minor ones, and (iii) on deposits of small active debris flows in the eastern part of the surveyed area (Fig. 6). Out of the white dot-and-dashed line, the presented data do not show realistic structures but rather artifacts. The Thorium map also showed a similar pattern (Fig. 7). Also the Uranium map (Fig. 8) showed locally the zones of minimum values similarly to the Potassium and Thorium maps. However, there were not registered any distinct relative maxima in contrary to the previous gamma ray maps. The last mapped was the isotope ${ }^{137} \mathrm{Cs}$. The maxima of the Cesuim were registered in areas composed of moraine deposits and dolomite with developed colluvium and soil cover, which appear on the orthophoto to be stable in past decades. On the other hand, the minima were recorded in zones, where the soil cover was removed by the major landslide, two minor landslides in the SW part of the area and on bare surfaces along the tension cracks and scarps in the tension zone of the crown.

\section{Discussion}

Although the airborne geophysical survey at the Stože landslide had to deal with many operational difficulties due to

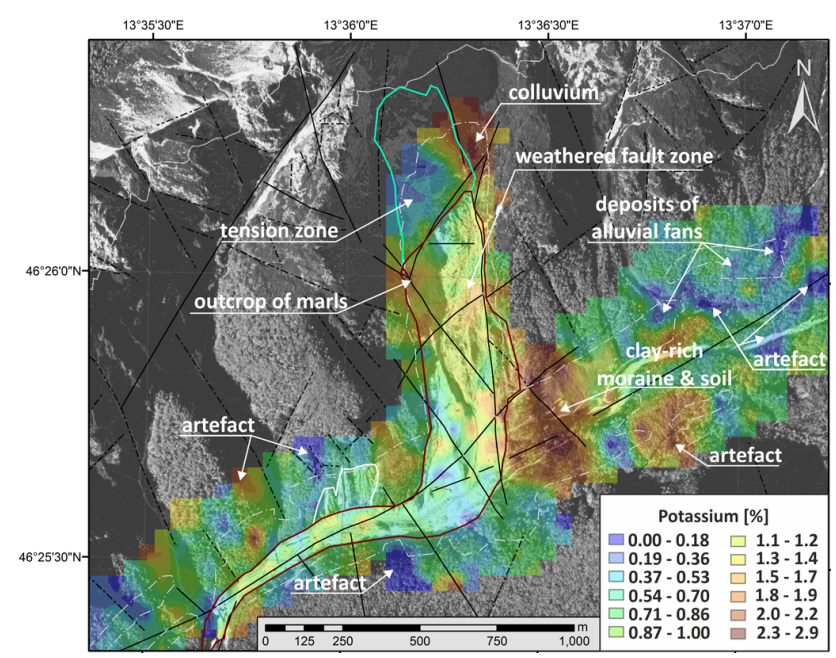

Fig. 6. Gamma ray survey: a map of Potassium combined with the fault and joint pattern (black full and dot-and-dashed lines), area of reliable data (light grey dot-and-dashed line) and the geological interpretation (Source of data: Geological Survey of Austria and Google Earth).

steep alpine slopes and bad weather, the case study proved its applicability for landslide detection, geological structure investigation, mapping of actual slope-related processes and mapping of landslide susceptibility even under difficult survey conditions.

The AEM survey showed the subsurface resistivity pattern over the test area presented in homogeneous half-space. The minima of the resistivity pattern of the surveyed area in the NW part of the landslide were attributed to the outcrop of marls rich in clay. In the lower part of the tension zone, the minimum resistivity was related most probably to water-saturated moraine deposit above impermeable marls. Also the elongated zone of minimum resistivity along the Koritnica River E of the landslide occurred probably due to water-saturation of porous alluvial gravel and landslide scree. The small minimum zone in the SW part of the surveyed area adjacent to the debris flow could be attributed to karst springs; however, this is not approved by any field survey. On the other hand, the maxima of resistivity reaching the values between 222 and $1122 \Omega \mathrm{m}$, which generally prevailed over the surveyed area, were related to well-drained and porous moraine deposit, to limestone and dolomite rock and to loosened material of the moraine deposit in the tension zone of the landslide with present cracks and cavities. As conclusion, the AEM survey confirmed the lithological pattern and water saturation within the test area.

Since the survey area is too small with respect to the minimum size of detectable structures, the achieved map of magnetic anomalies is difficult to be interpreted. Therefore we must state that the airborne magnetic survey provided for such a small area with such a high relative relief is unfortunately inapplicable. 


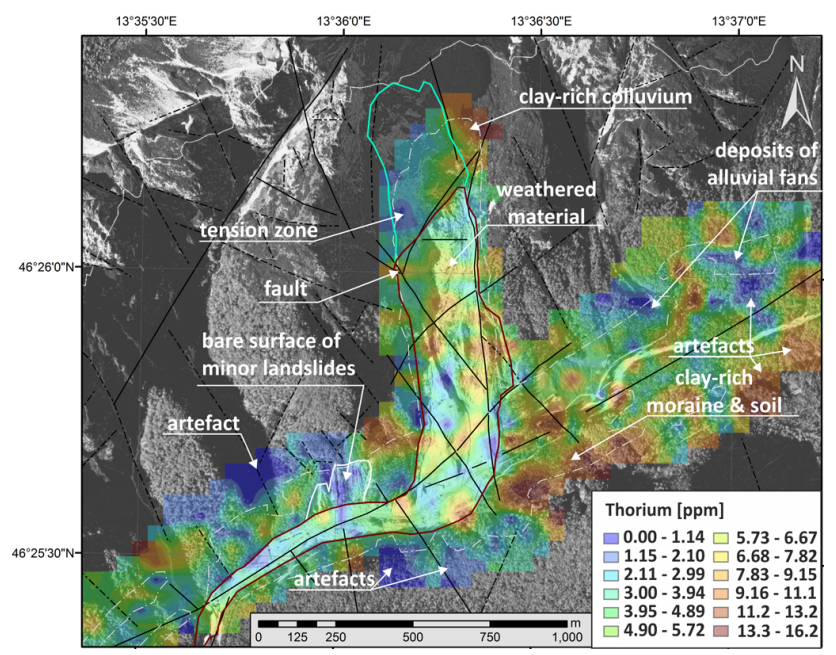

Fig. 7. Gamma ray survey: a map of Thorium combined with the fault and joint pattern (black full and dot-and-dashed lines), area of reliable data (light grey dot-and-dashed line) and the geological interpretation; the units are parts per million [ppm] (Source of data: Geological Survey of Austria and Google Earth).

On the other hand, the gamma ray survey shows very promising results for landslide studies. When compared to the information on local geology, especially the maxima of Potassium and Thorium both well identified the regions relatively rich in clay along the outcrops of marls, of clay-rich colluvium, weathered zones along some tectonic faults and clay rich parts of moraines, thus zones with a lithology relatively prone to mass wasting. The zones of relative minima of Potassium, Thorium and Uranium were attributed to porous, loosened material, tension cracks, and debris flow and alluvial deposits, which all are characteristic with intense leaching, material erosion and soil removal. The areas of minima of the ${ }^{137} \mathrm{Cs}$ were related to the zones of distinct material removal due to recent mass movements. However, one must, be very careful interpreting the zones along the margins of the surveyed area because of false results (artifacts) due to interpolation (see Figs. 6, 7, 8 and 9).

As shown by our test study, airborne geophysical surveys, especially due to their relatively low resolution in contrary to the ground-based geophysical methods, bring rather information on the bedrock properties of broader areas than on the landslides' internal structures themselves. AEM data reveal the clay content and water saturation in depth, whereas gamma ray indicated especially the clay content near the ground surface (Thorium and Potassium), or indicate material removal after $1986\left({ }^{137} \mathrm{Cs}\right)$. However, in the case of such small areas such as the Stože test site, the airborne geophysical data have some interpretational constraints. The integration of the results measured on the landslide body into the geophysical signature of the background of the surrounding area is very difficult. Therefore, proper and detailed comparing the results to other geological and geomorphic data

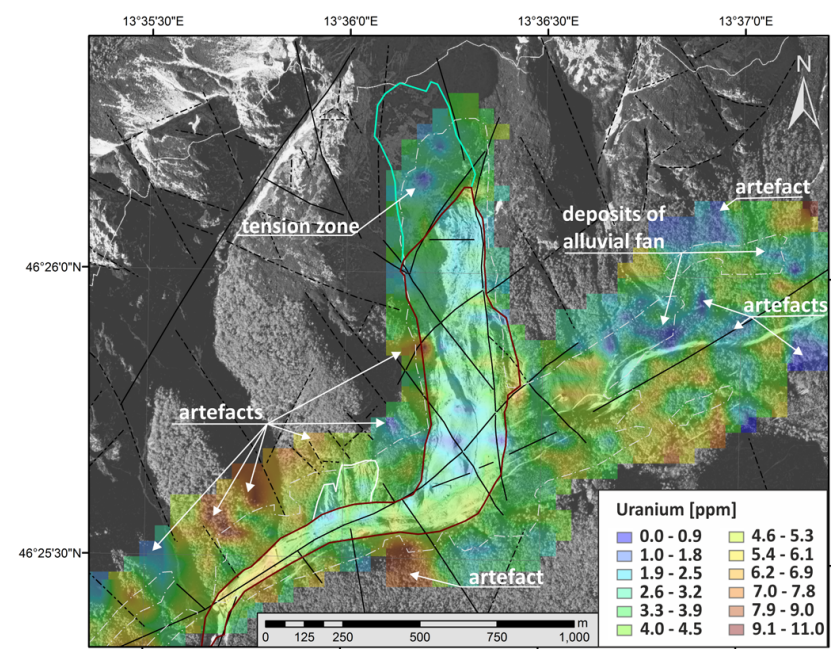

Fig. 8. Gamma ray survey: a map of Uranium combined with the fault and joint pattern (black full and dot-and-dashed lines), area of reliable data (light grey dot-and-dashed line) and the geological interpretation; the units are parts per million [ppm] (Source of data: Geological Survey of Austria and Google Earth).

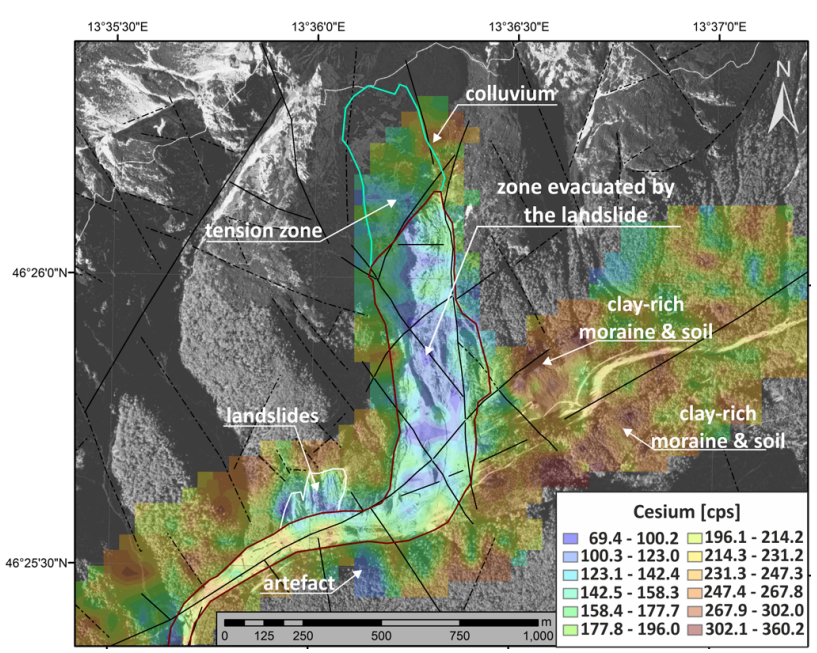

Fig. 9. Gamma ray survey: a map of Cesium combined with the fault and joint pattern (black full and dot-and-dashed lines), and the geological interpretation; the units are counts per second [cps] (Source of data: Geological Survey of Austria and Google Earth).

available is necessary. One should also keep an eye on the reliability of the results along the margins of the surveyed areas as non-realistic artifacts can usually occur due to data interpolation. Those false areas are relatively large in respect to the proportions of such small areas.

The study also proved some practical issues of the airborne geophysical surveys. The best situation is when the project budget allows several hours of training flights for the pilot and permits to wait for optimum flying conditions. Such a trained pilot could in suitable weather conditions 
significantly decrease the average value of the sensor altitudes and keep them as constant as possible, which would significantly improve the quality of the electromagnetic results. On the other hand this study, in agreement with our another study from Gschliefgraben in Austria (Supper et al., 2013) has shown that even with a stronger helicopter a much larger area could not have been covered with data due to the steep cliffs. Consequently, the question arises, if the limited coverage of the area justifies the high costs (mobilization of helicopter and data acquisition crew, flight costs, personal costs for the survey) of an optimized airborne survey for such a relatively small investigation area in such rough terrain conditions.

\section{Conclusions}

Our study tested the applicability of the airborne multiparametric geophysical survey for landslides in steep alpine terrains. Despite of several operational challenges (including limited time and budget, steep morphology and bad weather conditions), the AEM survey showed the lithological pattern and water saturation. The high resistivity regions mostly indicated the dolomite and limestone rock, drained slope scree and landslide mass, drained and loosened material of the moraine deposit in the tension zone of the landslide with present cracks and cavities. The minima of the resistivity pattern were attributed to the outcrop of marls rich in clay, to water-saturated moraine deposit above impermeable marls in the tension zone, and to water-saturated porous alluvial gravel and landslide scree along the Koritnica River. The magnetic survey proved to be inapplicable for such a small and rough area.

The minima in Potassium and Thorium maps both identified the regions of tension inside the landslide zone and fluvial deposits and deposits of debris flows in alluvial fans; the maxima on the other hand, revealed lithology relatively rich in clay, i.e., outcrops of marls, clay-rich colluvium, and weathered zones along a regional tectonic fault. The minima of the ${ }^{137} \mathrm{Cs}$ clearly revealed the zones of material removal due to recent mass movements.

In spite of all the topographic restrictions of this test site, the airborne geophysical survey of such a small and steep area was still possible and brought valuable information on the subsurface geophysical properties. However, comparing our results with those obtained by Supper et al. (2013), we conclude that for site specific, small scale studies under rough terrain conditions, like the one investigated at Stože, airborne geophysics might not be the method of choice taking into account the high costs and the limited resolution of the data. Nevertheless, when larger areas or several sites situated close to each other, airborne geophysics would definitely be the suitable method to be applied due to its multi sensor surveying ability.
Acknowledgements. The present work has been partially supported by the project SafeLand "Living with landslide risk in Europe: Assessment, effects of global change, and risk management strategies" (7th Framework Programme of the European Commission, Grant Agreement No. 226479). This support is gratefully acknowledged. The authors would like to thank to Clement Michoud and other two anonymous referees for their useful comments and suggestions, which improved the quality of the manuscript.

Edited by: S. Segoni

Reviewed by: C. Michoud, A. Agostini, and one anonymous referee

\section{References}

Ahl, A.: Automatic 1D inversion of multifrequency airborne electromagnetic data with artificial neural networks: discussion and a case study, Geophys. Prospect., 51, 89-98, 2003.

Jurkovšek, B.: Geological map and explanatory text of areas of Beljak and Ponteba, series of basic geological maps of SFRJ at a scale of 1:100,000. Federal Geological Survey of Yugoslavia, Beograd, 58 pp., 1987.

Komac, B.: Geographical Aspects of the Disaster in Log pod Mangartom, Ujma, 14-15, 2000/2001, Ljubljana, 2001.

Majes, B.: Analyses of Landslide and its Rehabilitation, Ujma, 1415, 2000/2001, Ljubljana, 2001.

Mikoš, M., Fazarinc, R., and Majes, B.: Določitev ogroženega območja v Logu pod Mangartom zaradi drobirskih tokov s plazu Stože, Acta Geogr. Slov., 47-2, 171-198, 2007 (in Slovenian).

Motschka, K.: Aerogeophysics in Austria, Bulletin of the Geological Survey of Japan, 52, 83-88, 2001.

Nakazato, H., Kuroda, S., Okuyama, T., and Sasaki, Y.: The aim at a rich rural village utilizing water and soil. Improvement of production basis for improving productivity and exhibiting many-sided functions, and development of management techniques - Improvement of airborne electromagnetic method and three-dimensional resistivity distribution exploration in landslide areas. Mizu to Tsuchi o Ikashi Yutakana Noson o Mezashite Saishin Nogyo Kogaku Kenkyu Seikashu Heisei 18nen, 216217, 2006.

Petkovšek, B.: Geological Charachteristic of the Stože Landslide, Ujma, 14-15, 2000/2001, Ljubljana, 2001.

Petrica, R. and Špacapan, I.: Landslide Stože - GeologicalGeotechnical Investigation: Engineering-geological map, ZRMK, Ljubljana, 2001 (in Slovenian).

Pfaffhuber, A. A., Grimstad, E., Domaas, U., Auken, E., Halkjær, M.: The hunt for sliding planes in a phyllitic rock slide inWestern Norway using airborne electromagnetic mapping, Geophys. Res. Abstr., EGU2010-4492, EGU General Assembly 2010, Vienna, Austria, 2010.

Siehl, A.: Umweltradioaktivität, Ernst \& Sohn, Berlin, 1996 (in German).

Supper, R., Römer, A., Jochum, B., Bieber, G., and Jaritz, W.: A complex geo-scientific strategy for landslide hazard mitigation from airborne mapping to ground monitoring, Adv. Geosci., 14, 195-200, doi:10.5194/adgeo-14-195-2008, 2008.

Supper, R., Baroň, I., Jochum, B., Ita, A., Motschka, K., and Winkler, E.: Airborne Geophysics and Geoelectric and Inclinometric Monitoring at the Gschliefgraben Landslide, in: Landslide Moni- 
toring Technologies \& Early Warning Systems, Ber. Geol. B.-A., 82, 50-56, 2010.

Supper, R., Baroň, I., Ottowitz, D., Motschka, K., Gruber, S., Winkler, E., Jochum, B., and Römer, A.: Airborne geophysical mapping as an innovative methodology for landslide investigation: evaluation of results from the Gschliefgraben landslide, Austria, Nat. Hazards Earth Syst. Sci. Discuss., 1, 2281-2318, doi:10.5194/nhessd-1-2281-2013, 2013.

Tofani, V., Segoni, S., Agostini, A., Catani, F., and Casagli, N.: Technical Note: Use of remote sensing for landslide studies in Europe, Nat. Hazards Earth Syst. Sci., 13, 299-309, doi:10.5194/nhess-13-299-2013, 2013.
Vidrih, R. and Ribičič, M.: Slope Failure Effects in Rocks at Earthquake - Posočje, 12 April 1998 and European Macroseismic Scale (EMS-98), Geologija, 41, 365-419 (1998), Ljubljana, 1999.

Vidrih, R. and Ribičič, M.: The earthquake on July 12, 2004, in Upper Soča Valley (NW Slovenia) - preliminary geological and seismological characteristic, Geologija, 47/2, 199-220, Ljubljana, 2004. 